\title{
Overview on Inequality Aversion and Credit Fulfillment
}

\author{
Xin-Ke Ju* \\ School of Economics and Management, Nanjing University of Science and Technology \\ Nanjing, 210094, P. R. China \\ email: leslieju@qq.com
}

Keywords: Inequality Aversion; Credit Fulfillment; Credit Contract; Games; Overview

\begin{abstract}
A lot of economy experiments indicate that human beings have the social preferences in addition to maximize their material benefits. The preferences are common. Among them, the inequality aversion is one of the important components of social preferences. From the inequality aversion point of view, many economic behaviors and decision-making problems could be explained and understood. The credit honors problem is one of them. In recent years, the causes of credit infringement and prevention are the hot topics in finances. This article summarizes the current trend and progress of inequality aversion and credit insurance.
\end{abstract}

\section{Introduction}

Ever since economics is set up, it uses the hypothesis of "self-interest" or "maximization of an individual benefit" as a prerequisite for basic analyses. But with the development of experiment economics, large amount of experiment indicates that except running after their own maximum material benefits, people also has the social preferences, and this preference is very common. Experiments that are related to this behavior mainly include trust experiment, gift exchange experiment, ultimatum experiment and public goods experiment. Therefore, people's credit honors agreement behavior is not driven only by their material benefits. If we apply social preferences theory, we will be able to explain a series of paradox revealed by experiment economics. Discussion about credit honor agreement problem, especially about debit and credit return between the strangers is as old as the hills. Due to the lack of a mandatory third party restraint mechanism or information asymmetry problem, inequality aversion of borrower and lender becomes the main factor for returning money.

\section{Research about Inequality Aversion Problem}

Cognition of Inequality Aversion. Under the hypothetic condition of rational self-interested people, people only care about their own material wealth. But economy experiment research over the past many years indicates that quite some people also care about other peoples' wealth. Many people are not only willing to spend resource to increase others people's gain under certain circumstances, but also willing to spend resource to cut down others people's gain in other circumstances, even though these money spent can't increase their own payoffs now or in long-term. This indicates that except self-interested behavior, people show social preferences. Camerer (2002) summarized society preferences into three major kinds _ altruistic preferences, and preferences for equality and for reciprocity. And he made the following differentiation: Reciprocity which is different from reciprocal altruism in evolutional biology, it refers to that people are willing to reward amiable behavior but punishing for not amicable behavior, even if this reward or punishment makes oneself pay a price of material wealth. This means that reciprocal behavior is for cooperation mutually. Inequality aversion preferences make people willing to spend material payoff to reduce inequality. Altruism is different from reciprocity, in that people spend material wealth to increase others' gain, which has nothing to do 
with the previous behavior of the other party. That is, altruism is being unconditionally amicable but reciprocity represents non-selfish behavior based on the condition of others' previous behavior [1].

Society preferences have various classifications. Song (2011), for instance, regarded that the jealousy is a kind of society preferences according to the published literatures, which is the opposite of altruism, it is to be jealous or the deliberately destroyer. These social preferences have negative utility on the other party, even though it increases their own cost (Bolton, 1991; Kirchsteiger, 1994; Mui, 1995). This kind of social preferences is harmful to our society [2-5]. There are some differences among inequality aversion preferences, which mainly differentiate whether motivation is counted into the analysis range of inequality aversion preferences. Song (2011) thought that there are two kinds of equality preferences: result-based impartial preferences and motivation-based impartial preferences [2]. Liu et al (2012) categorized social preferences into two kinds: distribution preference which cares about the result and reciprocity which cares about the intension behind the behaviors [6]. Though all above statements are not consensus with each other, we can see the diversity of understanding about inequality aversion preferences. One opinion views inequality aversion preferences as the consideration of results, this theory is easy to verify in the research, but not perfect enough. The other opinion thinks that an inequality aversion may originate from result or from motivation. If the inequality aversion preferences motivation, it is hard to differentiate from reciprocity, especially in how to set up measurement by controlling conditions in economy experiments.

The Model for Inequality Aversion Preference. Result-based inequality aversion models mainly include those of Fehr and Schmidt (1999), Bolton and Ockenfels (2000) and etc [7-8]. Fehr and Schmidt (1999) defined equality as self-centered inequality aversion. Self-centered means people only care about their own relative payoff, they do not care about the inequality for other people. They assumed that the participants not only care about their own payoff, but also care about the difference between their payoffs versus other people's [9]. Bolton and Ockenfels' model (2000) is ERC (Equity, Reciprocity and Competition). The novelty in Bolton and Ockenfels (2000) is that an individual is not only driven by his/her absolute payoff, but also motivated by the relative payoff. Bolton and Ockenfels (2000) model is somewhat different from those of Fehr and Schmidt (1999) in details. For example, the latter assumes that people compare their own payoff with every other participant's payoff while the former emphasizes that people will compare their own payoff with the average of other people's payoff. The latter model is a complete information model, but the former is an incomplete one [9].

Motivation-based inequality aversion models mainly include Rabin's [10]. But Rabin calls the game in his model psychological games, not the popular material games. Take a two-person game as example, which is different from the gamers who only care about their own payoff. If the gamer 1 think that gamer 2's motivation is "good", the tactics that gamer 1 adopts is beneficial to gamer 2; If gamer 1 think that gamer 2's motivation is "bad". The tactics that gamer 1 adopts will be harmful to gamer 2 . In short, gamer 1's response not only depends on his own payoff, but also depends on his belief of gamer 2's motivation [11].

Distribution fairness emphasizes that the result is impartial. The behavior person may possibly sacrifice part of his payoff for the impartial payoff distribution. Behavior motivation equality is to emphasize that the behavior motivation is mutually equal. The behavior person sacrifices part of his payoff for repaying favor or revenging. In fact, decision-making behavior is influenced both by payoff distribution result and behavior motivation. Therefore, a lot of economists attempt to establish an integrate model with an amalgamation of payoff quality and behavior motivation quality. These are able to explain the game experiment results, but they are based on psychological game, and have multiple balancing results, their feasibility is less [12]. For instance, by improving and extending Rabin's model, Falk and Fischbacher (2001) has defined reciprocity equilibrium, and Charness and Rabin (2002) has defined reciprocal fairness equilibrium [13-14].

Experiments of Inequality Aversion Preference. There are two major measurements for the inequality aversions. 1) Measurement of inequality aversion to the decision-making. For instance, Yin 
et al (2012) investigated the influence of equality to the individual decision process [15]. Song et al (2011) established the relationship of the unequal income, social preferences and public goods supply in a standard voluntary public goods experiment. During the study, three unequal situations are the unequal initial endowments, unequal marginal private return from a contribution to the group project and unequal appearance fees. It shows that the behavior of individual public invest could mainly explained by reciprocity and inequality aversion [16]. Rao et al (2009) explained why centipede game's experimental results have the systematic deviations from traditional theoretical results, by taking individuals' equality preferences into consideration [17]. All the above experiments demonstrate that the inequality aversion is one of the causes of decision makings. To probe what type of the inequality aversion affects the decision makings more, Chen et al (2011) designed a set of ultimatum experiments to exam the influences of equality of both assignment motivation and assignment result on the behavior of decision-making. The experiment indicated that the fairness of assigning motivation affects the decision-making behavior more than the fairness of assigning result [18]. 2) Measurement of the influences of other factors when the inequality aversion is controllable. For instance, Song et al (2011) investigated the effects of two types of punishments on public goods supply in an unequal environment of payoff. The experiment demonstrated the public goods supply is notably and stably enhanced by introducing some kind of punishments under unequal environment of payoff [19].

\section{Research on Fulfillment of Credit Contract}

The Cause of Breaking a Contract. The main bodies of credit infringement studies are medium-sized and small enterprises. For this purpose, Huang (2007) summarized three causes of enterprise credit infringement: One cause is the information asymmetry between loaner and debtor, and the limited liability that involve adverse selections and moral risks (Stiglitz 1981); Another cause is the dynamic inconsistency in the game of borrowers and lenders (validity after the event) that brings about soft restrain for bank credit (Dewartripont and Maskin 1994, 1995); The last cause is from viewpoint of financial affairs, the debtor is unable to fulfill the credit contract due to the failure of management as being presented by Merton model [20]. Lin (2009) analyzed the factors of credit default from three aspects that are small enterprise itself, banking institution and outside environment [21]. In addition, Song et al (2005) analyzed the main reasons of credit soft constraint, and thought that the multi-control of relation contract, commanding plan and law compulsion brought forth an increase of contract trade cost [22]. Besides, credit infringement exists in individual debit and credit. Zhang et al (2013) analyzed the factors that influence the credit default of peasant household in the cooperated financial institution of Shaanxi rural area [23].

Management of Credit Contract. There are researches about the credit contract management from different viewpoints. It is of importance to study the credit contract with high compliance rate. For instance, Han et al (2009) applied game theory to analyze the credit contract with high compliance rate in the agriculture herding corps in Xinjiang. Some key factors in controlling the credit contract could be brought forward by analyzing the causes of contract failure. For instance, Liang (2007) established a supervision model for the fulfillment of credit contract, with focus on guarantee of creditor's rights and interests [24]; Song et al (2010) discussed the conditions to realize credit contract from three aspects of debt mechanism. These are the ability and motivity of banking supervision, and stimulation of credit contract and feasibility of supervision [25]; Liu (2006) probed how the social norm enforces micro-credit contract self-compliance [26].

Study of Financial Products in Credit Fulfillment. The credit contract insurance is the main financial products being designed specifically for the breach of a credit contract. The insurance company promises to compensate for losses of obligee with the insurance premium when the debtor is fail to fulfill the credit contract. It is an insurance product on the basis of debtor's fulfillment [27]. The 
available literatures paid close attention to the risk control of the insurance and the insurance cognition (Liu 2003; Li 2012) [27-28].

\section{Inequality Aversion and Credit Fulfillment}

In experiment economics, one can use trust game to study the fulfillment of credit contract. Person A in the trust experiment owns an initial endowment $S$ and decides to invest $y$ amount in person $B$ to obtain an investment value. The values of $y$ are between 0 and $S$. Person $B$ is able to gain three times of investment returning, and decides to return $x$ to person A. Therefore, A's payoff is $S-y+x$, B's is $3 y$

$-\mathrm{x}$. By using the framework of this experiment, the experiment of credit contract could be described basically as: the creditor B owns an initial value of S, debtor A applies a loan from creditor B, and the application includes loan $\mathrm{y}$ and repayment $\mathrm{x}$. The values of $\mathrm{y}$ are 0 to $\mathrm{S}$. The creditor $\mathrm{B}$ decides whether or not to approve the loan application. Creditor B will gain three times of investment returning of 3y and return $\mathrm{x}$ to $\mathrm{B}$, if he agrees the loan. Similarly, the net income of A is $\mathrm{S}-\mathrm{y}+\mathrm{x}$, and $\mathrm{B}$ is $3 \mathrm{y}-\mathrm{x}$. Otherwise, both sides of borrow and loan fail and have no invest income.

Wei et al (2006) thought that the game experiments in convincing fairness preferences include the ultimatum game, gift exchange game, trust game, dictator game and public goods game etc. These games are simple, yet easy to handle and repeat. Thus, they have sufficient stringency as a result [12]. Therefore, in the evaluation of contract behaviors of credit contract, one needs to consider the inequality aversion as an important factor to analyze the credit fulfillment.

\section{Summary}

The inequality aversion is an important component of social preferences. More and more literatures explain people's decision-making behaviors in viewpoint of inequality aversion. The inequality aversion, credit fulfillment and their relevancy were overviewed. New progresses in this field and the hot topics of credit fulfillment were summarized.

\section{Acknowledgements}

The author thanks the Innovation Project for Postgraduates of NJUST for partial financial support.

\section{References}

[1] C.F. Camerer and E. Fehr, Measuring social norms and preferences using experimental games: A guide for social scientists. Working Paper Series, (2002) No. 97, p.1-38.

[2] G.E. Bolton, A comparative model of bargaining: Theory and evidence. The American Economic Review, Vol. 81 (1991) No. 5, p.1096-1136.

[3] G. Kirchsteiger, The role of envy in ultimatum games. Journal of Economic Behavior \& Organization, Vol. 25 (1994) No. 3, p.373-389.

[4] V.L. Mui, The economics of envy. Journal of Economic Behavior \& Organization, Vol. 26 (1995) No. 3, p.311-336.

[5] J.H. Song, A review of experimental economics based on fairness preference. Economic Review, (2011) No. 3, p.124-130. (In Chinese)

[6] M. Liu, F.Y. Fei and J. Sun, Review on the researches of the identification of economic experiments on social preferences. Economist, (2012) No. 8, p.91-98. (In Chinese)

[7] E. Fehr and K.M. Schmidt, A theory of fairness, competition, and cooperation. Quarterly Journal of Economics, Vol. 114 (1999) No. 3, p.817-868.

[8] G.E. Bolton and A. Ockenfels, ERC: A theory of equity, reciprocity, and competition. American Economic Review, Vol. 90 (2000) No. 1, p.166-193. 
[9] J. Wei, Economics of incorporating fairness: Theory and evidence. Economic Research, (2010) No. 9, p.137-148. (In Chinese)

[10] M. Rabin, Incorporating fairness into game theory and economics. The American Economic Review, Vol. 83 (1993) No. 5, p.1281-1302.

[11] W.R. Gong and F.Y. Fei, Equality-prefered economic man: A review of experimental economics. Economist, (2006) No. 2, p.32-39. (In Chinese)

[12] G.X. Wei, A survey of game experiments and theoretical models on fairness preference. Digit Economic Technology and Research, Vol. 23 (2006) No. 8, p.152-160. (In Chinese)

[13] A. Falk and U. Fischbacher, A theory of reciprocity. Games and Economic Behavior, Vol. 54 (2006) No. 2, p.293-315.

[14] G. Charness and M. Rabin, Understanding social preferences with simple tests. Quarterly Journal of Economics, Vol. 117 (2002) No. 3, p.817-869.

[15] J. Yin and B.L. Lv, Analysis of fair induction and decision making in improved three party ultimatum game. Commercial Era, (2012) No. 25, p.106-109. (In Chinese)

[16] Z.F. Song, Y.A. Zhou and Q.X. He, The unequal aversion and the voluntary provision of public goods - a preliminary research based on experimental economics. Management World, (2011) No. 12, p.32-54. (In Chinese)

[17] Y.L. Rao, J.X. Wang and Y.Y. Chen, Behavioral game model and simulating based on heterogeneous fairness preference: An explanation to the results of centipede game experiments. Systems Engineering, Vol. 27 (2009) No. 3, p.93-98. (In Chinese)

[18] Y.F. Chen, Y.A. Zhou and Z.F. Song, Inequality aversion or reciprocity? ——An investigation of two kinds of fairness in the ultimatum game. Economic Research, (2011) No. 6, p.31-44. (In Chinese)

[19] Z.F. Song and Y.A. Zhou, Experiemntal ecomomics research on MPCR equality, sanction and voluntary public goods supply. World Economics, (2011) No. 10, p.35-54. (In Chinese)

[20] Z.H. Huang, A review of corporation default behavior theory. Zhejiang Finance, (2007) No. 1, p.53. (In Chinese)

[21] Q. Lin, The analysis of factors about small corpration default. Southeast Academic Research, (2009) No. 4, p.103-109. (In Chinese)

[22] Y.H. Song and D.F. Yu, Soft constraint of credit contract during the transformation period. Journal of Zhejiang University (Philosophy and Social Sciences), Vol. 35 (2005) No. 4, p.44-51. (In Chinese)

[23] Y.Y. Zhang, Research on the influence factors and control of rural cooperative financial institution's credit risk in Shaanxi province. (Ph.D., Northwest A\&F University, China 2013), p.1-146 (In Chinese)

[24] H.F. Liang, Incentives to monitor borrowers in fulfilling loan contracts. Journal of Peking University (Philosophy and Social Sciences), Vol. 44 (2007) No. 4, p.23-30. (In Chinese)

[25] S.Q. Song, The governance effect of the credit contract (Ph.D., Dongbei University of Finance and Economics, China 2010), p.1-125 (In Chinese)

[26] J. Liu, Discussion on how the community norms reinforce the fulfillment mechanism of microfinance. Shandong Economy, Vol. 22 (2006) No. 1, p.67-70. (In Chinese)

[27] Z.H. Liu and L. Chang, The risk prevention of credit contract insurance and personal consumption credit business. Southwest Finance, (2003) No. 8, p.54-57. (In Chinese)

[28] H.F. Li, The risk management of credit contract insurance. China Finance, (2012) No. 4, p.79-80. (In Chinese) 